\author{
종자피복기의 피복통 회전속도가 피복종자의 물리적 특성에 \\ 미치는 영향 \\ 허삼남 · 이성운* · 박천수 · 장 박 · 박홍석
}

\title{
Effects of Rotatory Speed of Coating Pan on the Physical Characteristics of Coated Seeds
}

\author{
Sam Nam Hur, Cheng Yun Li*, Chun Soo Park, Bo Zhang and Hong Suk Park
}

\begin{abstract}
Using a small pilot coating pan, red clover and tall fescue seeds were coated under different rotating speed of pan (20, 30, 40, 45, 55, $60 \mathrm{rpm})$ for standardization of seed coating. Vermiculite was used as particulate matter and polyvinyl alcohol as adhesive for the coating of seeds. Coating index was calculated based on the percent singles out, percent agglomerates out, weight of particulate matter fine, percent friability, and average weight per 100 seeds to evaluate the physical characteristics of coated seeds. The coated seed of red clover under $45 \mathrm{rpm}$ rotating speed of pan, was best in terms of percent singles out, percent agglomerates out, weight of fines, and average 100 seed weight. The coated seed of tall fescue under $40 \mathrm{rpm}$ rotating speed of pan, showed highest percent singles out, lowest percent agglomerates out, lowest weight of fines, and heaviest average 100 seed weight. Excellent coating results were obtained with the pan speed of $45 \mathrm{rpm}$ for red clover and $40 \mathrm{rpm}$ for tall fescue seeds. As rotatory speed of coating pan affected much to the physical characteristics of coated seeds, standardization of the speed is required before seed coating.
\end{abstract}

(Key words : Coating pan, Coating index, Seed coating, Red clover, Tall fescue)

\section{I. 서 론}

종자피복 표준화 생산기술은 반복적인 생산 과정을 거치더라도 항상 동일품질의 피복종자 를 생산할 수 있어야 한다. 하지만 피복통의 회전속도, 접착제의 종류, 농도 및 분무량, 종 자의 형태와 양, 그리고 고형물질의 물리적 형 태(고체 또는 액체)나 첨가량 등 여러 요인에 따라 피복효과가 모두 다르게 나타나기 때문에 (Scott 등, 1997) 이의 표준화가 필요하다. 피복
종자의 표준화를 위해서는 일차적으로 피복기 계 회전속도의 표준화가 선행되어야 한다. 그 리고 표준화된 종자를 평가하기 위해서는 피복 종자의 물리적인 평가가 이루어져야 되는데 종 자 피복 관련 문헌 중에서 참고할만한 물리적 인 품질평가 방법에 관한 보고는 매우 드물다. 다만 일부 종자피복 관련 연구에서는 액상피복 (液床被覆, fluid bed coating) 방법을 이용한 종 자피복에 관한 피복기술이 보고되었으며, 피복 제의 물리적인 성질, 종자의 형태나 양에 따라

전북대학교(Chonbuk National Univ. Chonju 561-756, Korea)

* 중국 연변대학 농학원(College of Agriculture, Yanbian Univ.)

Corresponding author : Sam Nam Hur, Chonbuk National Univ. Chonju 561-756, Korea.

Tel: +82-63-270-2610, Fax: +82-63-270-2612, E-mail: hsn@chonbuk.ac.kr 
피복종자의 물리적인 품질이 크게 달라진다고 하였다(Liu와 Litster 1989; 1990). Scott 등 (1997)은 피복 후 회수된 전체 무게, 단립피복 종자, 서로 달라붙어 덩어리진 피복종자, 피복 되지 않고 회수된 미 피복물질 등 여러 변수들 을 측정하여 이 들의 변수 조합으로 피복지수 를 도출하여 피복종자의 물리적인 품질을 평가 하였다. 그는 피복통(coating pan, 직경 $285 \mathrm{~mm}$, 길이 $195 \mathrm{~mm}$ ), 자동 속도 조절기, 속도 모터 (speed motor, 0 100 rpm)와 건조기(drier)로 구 성된 소형 회전통(rotating drum)을 자체 제작하 여 종자피복 연구에 이용하였으며, Fraser (1966)도 소형 회전통(rotating drum)을 이용하 여 여러 가지 종자 피복실험을 수행하였다. 이 러한 소형 회전 피복통은 대형 상업용 피복기 에 비해 비용이 적게 들고 조작이 간편하며 실 험에서 사용이 편리하기 때문에 종자피복 실험 에 널리 이용되고 있다. 국내에서는 아직 피복 종자를 생산하는 전문회사가 없으며 종자피복 에 관한 표준화 실험도 이루어지지 않았다.

따라서 본 연구에서는 자체 제작한 실험용 소형 종자 피복통을 이용하여 피복통의 회전속 도별로 공시종자인 레드클로버(red clover)와 톨 페스큐(tall fescue) 피복종자의 물리적인 특성을 조사하고 통의 최적 회전속도를 표준화하여 고 품질의 피복종자 생산에 활용하기 위하여 본 연구를 수행하였다.

\section{II. 재료 및 방법}

\section{1. 종자 피복기계}

실험실용 종자피복기 (삼흥전공, 진주)는 피 복통의 직경이 $20.5 \mathrm{~cm}$, 깊이가 $23 \mathrm{~cm}$ 인 원통형 피복통과 분무기, 건조기, 속도조절기(0 100 rpm, Mitsubishi, Japan)로 구성되었으며, 통의 각도는 임의 조절이 가능하게 제작되었다. 분 무기는 접착제의 분무량을 조절할 수 있는 소 형 전기분무기 $(220 \mathrm{~V}, 0.8 \mathrm{~A}, 45 \mathrm{~W}$ TAIWAN)를
사용하였고, 건조기는 피복과정 중 종자의 건 조를 위하여 시중에서 판매되고 있는 3 단식 헤 어드라이어 $(220 \mathrm{~V}, 60 \mathrm{~Hz}, 1200 \mathrm{~W})$ 를 사용하였다.

\section{2. 피복 방법}

종자피복시 피복통의 기울기는 수평면과 $35^{\circ}$ 로 기울어지게 조절하였다. 접착제(폴리비닐 알 코올, polyvinyl alcohol) 분무량은 매 회당 $0.3 \mathrm{~g}$ 을 15초에 1 2회씩 분무기로 피복통에 분사하 였으며, 총 분무량은 분무횟수에 1 회분무량 $0.3 \mathrm{~g}$ 을 곱하여 산출하였다. 고형물질(버미큐라 이트, vermiculite)은 시약스푼으로 취하여 수시 로 피복통에 추가하였으며 피복시간은 30 50분 간 진행되었다. 피복진행과정 중 피복종자의 건조는 헤어드라이어를 이용하여 10 분 간격으 로 3 5분 동안 피복통 안에 더운 공기를 주입 하여 실시하였다. 피복통 회전속도는 피복통의 속도 제어장치로 각각 $20,30,40,45,55$ 및 60 $\mathrm{rpm}$ 으로 조절하여 피복종자의 물리적 특성을 조사하였다. 공시종자로 레드클로버(Trifolium pratense L.)와 톨페스큐(Festuca arundinacea Schreb.) 종자를 사용하였다.

\section{3. 피복종자의 물리성 품질 평가 방법}

피복종자의 물리성 품질평가는 Table 1에서 보여주는 것과 같이 Scott 등(1997)의 종자피복 평가시스템을 응용하여 실시하였다. 측정된 항 목은 총접착제 분무량(Z), 종자무게(A1), 고형 물질 첨가무게(A2), 종자피복 후 피복통에서 회수된 전체무게(B)이다. 그리고 회수된 전체 피복종자는 단립 피복종자(C), 서로 달라붙어 덩어리진 피복종자(D)와 피복되지 않고 회수된 미 피복 물질 $(\mathrm{E})$ 로 분리하여 각각 무게를 측정 하였다. 피복 시 피복통에 추가된 재료의 총 무게(A)와 회수된 무게(B)의 차이는 통에서 유 실되었거나 건조과정 중 건조에 의한 손실로 간주하고 그 양을 표시하였다. 그리고 피복된 
종자의 100 립중 $(\mathrm{H})$ 에서 무처리 종자의 100 립중 (G)을 공제한 차이를 피복된 피복물질 양(CR) 으로 하였다. 탈락정도 $(\mathrm{PF})$ 측정은 피복 후 건 조된 단립종자 $10 \mathrm{~g}$ 을 취하여 측정하였으며, 측 정설비는 자체 제작한 길이 $50 \mathrm{~cm}$, 직경이 5 $\mathrm{cm}$ 인 플라스틱 원통으로 한쪽 끝을 플라스틱 뚜껑으로 여닫게 제작하였다. 플라스틱 원통에 피복된 종자를 넣은 후 뚜껑을 닫고 수평면과 수직으로 축을 따라 $20 \mathrm{rpm}$ 에서 5분간 회전시 켜 원통 안의 종자가 $50 \mathrm{~cm}$ 높이에서 100 회의 충돌을 시킨 다음 종자를 회수하여 18메시 (mesh) 채로 쳐서 피복종자에서 탈락된 부서진 피복 재료를 제거하고 남은 무게를 측정하여
탈락정도를 계산하였다. 실험에 사용된 모든 피복종자는 $60^{\circ} \mathrm{C}$ 오븐에서 24 시간 건조시킨 후 에 사용하였다.

피복종자의 물리성 품질평가는 종합적인 피 복효과를 나타낼 수 있는 피복지수(I)를 산출하 여 평가하였다. 피복지수(I)는 첨가된 고형물질 의 무게(A2)에 대한 단립피복종자(WS) 중에서 깨지기 쉬운 단립피복종자(WF)를 제외한 백분 율로 표시하였다.

\section{4. 통계처리}

통계처리는 SAS ver 6.12(1991)를 이용하여

Table 1. Parameters involved in the evaluation of the physical quality of seed coating

\begin{tabular}{|c|c|c|c|c|c|}
\hline & W & $=$ & & & Number of spray bursts run $^{-1}$ \\
\hline & $\mathrm{X}$ & $=$ & & & Weight of adhesive burst ${ }^{-1}$ \\
\hline & $\mathrm{Y}$ & $=$ & & & Adhesive percentage particulate matter \\
\hline & $\mathrm{Z}$ & $=$ & $\left(\mathrm{W}^{*} \mathrm{X} * \mathrm{Y}\right) / 100$ & $=$ & Dry weight of adhesive \\
\hline$\Rightarrow$ & A1 & $=$ & & & Weight of raw seed in(g) \\
\hline$\Rightarrow$ & A2 & $=$ & & & Weight of coating particulate matter in (g) \\
\hline & A & $=$ & $\mathrm{Z}+\mathrm{A} 1+\mathrm{A} 2$ & $=$ & Gross weight in (g) \\
\hline$\Rightarrow$ & $\mathrm{B}$ & $=$ & & & Gross weight out (g) \\
\hline$\Rightarrow$ & $\mathrm{C}$ & $=$ & & & Weight of singles out (g) \\
\hline$\Rightarrow$ & $\mathrm{D}$ & $=$ & & & Weight of agglomerates out (g) \\
\hline & $\mathrm{E}$ & $=$ & $\mathrm{B}-(\mathrm{C}+\mathrm{D})$ & $=$ & Weight of fines (g) \\
\hline$\Rightarrow$ & $\mathrm{F}$ & $=$ & & & Percent friability \\
\hline$\Rightarrow$ & G & $=$ & & & Average weight per 100 raw seeds (g) \\
\hline$\Rightarrow$ & $\mathrm{H}$ & $=$ & & & Average weight per 100 coated seeds (g) \\
\hline & PR & $=$ & $(\mathrm{B} * 100) / \mathrm{A}$ & $=$ & Percent recovery \\
\hline & PL & $=$ & 100-PR & $=$ & Percent lost in coating pan \\
\hline & PA & $=$ & $\left(D^{*} 100\right) /(B-E)$ & $=$ & Percent agglomeration \\
\hline & $\mathrm{PF}$ & $=$ & $\left(\mathrm{E}^{*} 100\right) / \mathrm{A} 2$ & $=$ & Percent fines \\
\hline & $\mathrm{AF}$ & $=$ & $\left(\mathrm{F}^{*} \mathrm{~A}\right) /(\mathrm{A} 2-\mathrm{E})$ & $=$ & Adjusted percent friability \\
\hline & CR & $=$ & {$[(\mathrm{H}-\mathrm{G}) / \mathrm{G}]^{*} 100$} & $=$ & Coat : raw seed percentage ratio \\
\hline & WS & $=$ & {$[\mathrm{C} *(\mathrm{H}-\mathrm{G})] / \mathrm{H}$} & $=$ & Weight of coat in singles (g) \\
\hline & WF & $=$ & $\left(\mathrm{F}^{*} \mathrm{C}\right) / 100$ & $=$ & Weight of singles which is 'friable' \\
\hline & WSF & $=$ & WS-WF & $=$ & Weight of singles after friabilator (g) \\
\hline & CI & $=$ & $\left(\mathrm{WSF}^{*} 100\right) / \mathrm{A} 2$ & $=$ & Coating index \\
\hline
\end{tabular}

$\Rightarrow$ Input information required to enable calculations. 
분산분석을 실시하였다.

\section{III. 결과 및 고찰}

1. 피복통의 회전속도별 피복효과

레드클로버 종자의 피복통 회전속도별 피복 효과는 Table 2에서 보는 바와 같다. 피복 종료 후 통에서 회수된 단립 피복종자에 대한 피복 통에 첨가된 전체 재료의 비율은 통의 회전속 도가 $45 \mathrm{rpm}$ 일 때 $77.5 \%$ 로 유의하게 높게 나타 났다 $(\mathrm{p}<0.01)$. 통의 회전속도가 $45 \mathrm{rpm}$ 보다 증 가 혹은 감소함에 따라 회수되는 단립 피복 종 자 비율이 줄어들었다. 회수된 서로 달라붙어 덩어리 진 피복종자의 비율도 $45 \mathrm{rpm}$ 에서 제일 적었으며 $(\mathrm{p}<0.01)$, 통의 회전속도가 $45 \mathrm{rpm}$ 보 다 증가 혹은 감소함에 따라 서로 달라붙어 덩 어리 진 피복종자 비율이 증가되었다. 피복되 지 않고 회수된 미피복물질의 비율은 20, 30, 40 및 $45 \mathrm{rpm}$ 의 통 회전속도에서 $1.3 \sim 1.7 \%$ 사 이로 적었으며, 55와 $60 \mathrm{rpm}$ 에서는 2.8 및 3.8\% 로 크게 증가하였다. 충격에 의한 피복물질의 탈락성은 40 과 $45 \mathrm{rpm}$ 에서 각각 0.3 및 $0.2 \%$ 로 다른 처리들 보다 현저하게 적게 탈락되어 $(\mathrm{p}<0.01)$ 피복층이 쉽게 부서지지 않았다. 피복 종자의 백립중은 $45 \mathrm{rpm}$ 에서 $0.77 \mathrm{~g}$ 으로 여타
시험구보다 현저하게 높게 나타났고 $(\mathrm{p}<0.01)$, 회전속도가 $45 \mathrm{rpm}$ 보다 증가 혹은 감소됨에 따라 백립중이 감소되었다.

톨페스큐 종자의 피복통 회전속도별 피복효 과는 Table 3에서 보는 바와 같다. 통에서 회수 된 단립 피복종자 비율은 $40 \mathrm{rpm}$ 에서 $72.5 \%$ 로 제일 높게 나타났으며 $(\mathrm{p}<0.01)$, 회전속도가 40 $\mathrm{rpm}$ 보다 증가 혹은 감소함에 따라 회수되는 단립 피복종자 비율이 하락하는 경향을 나타내 었다. 회수된 서로 달라붙어 덩어리 진 피복 종자의 비율은 40 $55 \mathrm{rpm}$ 에서 $11.0 \%$ 로 낮았 다. 피복 후 통에서 회수된 미피복물질은 20, 30, 40 및 $45 \mathrm{rpm}$ 에서 4.3 4.5\%로 비슷하였으 며, 55 와 $60 \mathrm{rpm}$ 에서는 각각 5.5 및 $6.3 \%$ 로 증 가되었다. 피복종자의 충격에 의한 피복층의 탈락성은 40 과 $45 \mathrm{rpm}$ 에서 모두 $0.1 \%$ 로 가장 적었다 $(\mathrm{p}<0.01)$. 피복종자의 백립중은 $40 \mathrm{rpm}$ 에 서 $0.67 \mathrm{~g}$ 으로 제일 높았으며 $(\mathrm{p}<0.01)$ 회전속도 가 $40 \mathrm{rpm}$ 보다 증가 또는 감소함에 따라 백립 중이 감소하였다.

종자 피복과정에서 피복통의 회전속도는 피 복효과와 직접 관련되는 중요한 요인이다. 통 의 크기와 모양 및 각도에 따라 종자피복에 필 요한 통의 속도가 다르기 때문에 다른 형태의 피복통은 서로 다른 적정 회전속도를 필요로 한다. 강 등(1999)은 피복 드럼의 속도를 초기

Table 2. Coating efficiency of red clover seed depending on rotatory speed of coating pan

\begin{tabular}{cccccc}
\hline $\begin{array}{c}\text { Speed of } \\
\text { coating pan }\end{array}$ & $\begin{array}{c}\text { Percent } \\
\text { singles out } \\
(\%)\end{array}$ & $\begin{array}{c}\text { Percent } \\
\text { agglomerate } \\
\text { out (\%) }\end{array}$ & $\begin{array}{c}\text { Percent } \\
\text { fines } \\
(\%)\end{array}$ & $\begin{array}{c}\text { Percent } \\
\text { friability } \\
(\%)\end{array}$ & $\begin{array}{c}\text { Average weight } \\
\text { per 100 seeds } \\
(\mathrm{g})\end{array}$ \\
\hline \hline Intact & - & - & - & - & $0.21 \pm 0.017^{\mathrm{d}}$ \\
$20 \mathrm{rpm}$ & $54.5 \pm 3.06^{\mathrm{e}}{ }^{*}$ & $14.5 \pm 2.61^{\mathrm{a}}$ & $1.7 \pm 0.42^{\mathrm{c}}$ & $0.8 \pm 0.18^{\mathrm{a}}$ & $0.62 \pm 0.086^{\mathrm{c}}$ \\
$30 \mathrm{rpm}$ & $65.0 \pm 1.98^{\mathrm{bc}}$ & $12.3 \pm 2.80^{\mathrm{b}}$ & $1.7 \pm 0.25^{\mathrm{c}}$ & $0.5 \pm 0.18^{\mathrm{bc}}$ & $0.67 \pm 0.038^{\mathrm{bc}}$ \\
$40 \mathrm{rpm}$ & $69.8 \pm 2.40^{\mathrm{b}}$ & $11.8 \pm 2.36^{\mathrm{bc}}$ & $1.5 \pm 0.54^{\mathrm{c}}$ & $0.3 \pm 0.17^{\mathrm{d}}$ & $0.73 \pm 0.092^{\mathrm{ab}}$ \\
$45 \mathrm{rpm}$ & $77.5 \pm 1.54^{\mathrm{a}}$ & $11.0 \pm 1.38^{\mathrm{c}}$ & $1.3 \pm 0.25^{\mathrm{c}}$ & $0.2 \pm 0.30^{\mathrm{d}}$ & $0.77 \pm 0.083^{\mathrm{a}}$ \\
$55 \mathrm{rpm}$ & $67.0 \pm 2.55^{\mathrm{c}}$ & $11.8 \pm 1.30^{\mathrm{bc}}$ & $2.8 \pm 0.72^{\mathrm{b}}$ & $0.5 \pm 0.20^{\mathrm{bc}}$ & $0.71 \pm 0.087^{\mathrm{ab}}$ \\
$60 \mathrm{rpm}$ & $61.5 \pm 4.85^{\mathrm{d}}$ & $12.5 \pm 1.64^{\mathrm{b}}$ & $3.8 \pm 0.45^{\mathrm{a}}$ & $0.7 \pm 0.31^{\mathrm{b}}$ & $0.68 \pm 0.066^{\mathrm{bc}}$ \\
\hline
\end{tabular}

Mean \pm SD

* Means within the same column with different superscripts are significantly different $(\mathrm{p}<0.01)$. 
Table 3. Coating efficiency of red tall fescue seed depending on rotatory speed of coating pan

\begin{tabular}{cccccc}
\hline $\begin{array}{c}\text { Speed of } \\
\text { coating pan }\end{array}$ & $\begin{array}{c}\text { Percent } \\
\text { singles out } \\
(\%)\end{array}$ & $\begin{array}{c}\text { Percent } \\
\text { agglomerates } \\
\text { out(\%) }\end{array}$ & $\begin{array}{c}\text { Percent } \\
\text { fines } \\
(\%)\end{array}$ & $\begin{array}{c}\text { Percent } \\
\text { friability } \\
(\%)\end{array}$ & $\begin{array}{c}\text { Average weight } \\
\text { per 100 seeds } \\
(\mathrm{g})\end{array}$ \\
\hline \hline Intact & - & - & - & - & $0.19 \pm 0.018^{\mathrm{e}}$ \\
$20 \mathrm{rpm}$ & $54.7 \pm 2.94^{\mathrm{d} *}$ & $12.3 \pm 1.61^{\mathrm{a}}$ & $4.3 \pm 0.90^{\mathrm{b}}$ & $0.6 \pm 0.18^{\mathrm{a}}$ & $0.48 \pm 0.016^{\mathrm{d}}$ \\
$30 \mathrm{rpm}$ & $67.8 \pm 3.53^{\mathrm{b}}$ & $12.0 \pm 0.70^{\mathrm{a}}$ & $4.5 \pm 0.54^{\mathrm{b}}$ & $0.3 \pm 0.16^{\mathrm{b}}$ & $0.65 \pm 0.054^{\mathrm{ab}}$ \\
$40 \mathrm{rpm}$ & $72.5 \pm 1.44^{\mathrm{a}}$ & $11.0 \pm 1.02^{\mathrm{b}}$ & $4.5 \pm 0.60^{\mathrm{b}}$ & $0.1 \pm 0.06^{\mathrm{c}}$ & $0.67 \pm 0.073^{\mathrm{a}}$ \\
$45 \mathrm{rpm}$ & $65.8 \pm 4.68^{\mathrm{c}}$ & $11.0 \pm 1.26^{\mathrm{a}}$ & $4.3 \pm 0.36^{\mathrm{b}}$ & $0.1 \pm 0.07^{\mathrm{c}}$ & $0.63 \pm 0.068^{\mathrm{b}}$ \\
$55 \mathrm{rpm}$ & $57.5 \pm 1.18^{\mathrm{d}}$ & $11.0 \pm 0.84^{\mathrm{a}}$ & $5.5 \pm 0.66^{\mathrm{a}}$ & $0.3 \pm 0.24^{\mathrm{b}}$ & $0.60 \pm 0.047^{\mathrm{c}}$ \\
$60 \mathrm{rpm}$ & $53.3 \pm 3.48^{\mathrm{d}}$ & $11.5 \pm 0.60^{\mathrm{ab}}$ & $6.3 \pm 0.42^{\mathrm{a}}$ & $0.5 \pm 0.28^{\mathrm{a}}$ & $0.55 \pm 0.059^{\mathrm{c}}$ \\
\hline
\end{tabular}

Mean \pm SD.

* Means within the same a column with different superscripts are significantly different $(p<0.01)$.

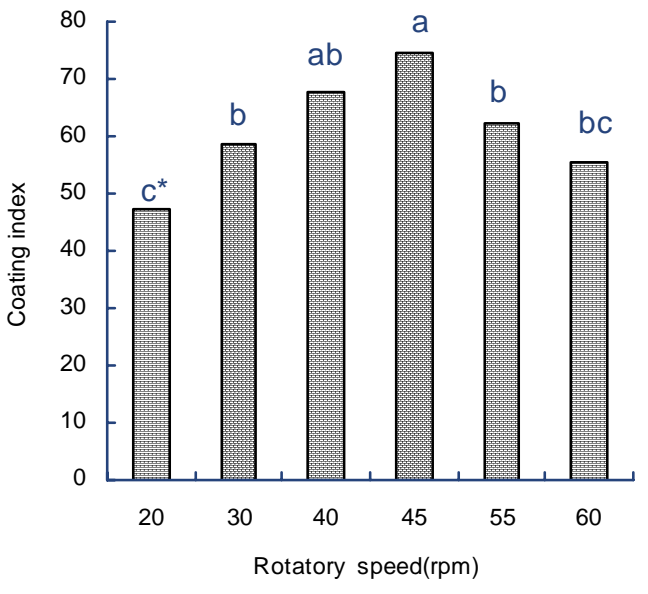

Fig. 1. Effects of coating pan speed on coating index for coating red clover seed.

* Bars with different alphabetic letters are significantly different $(\mathrm{p}<0.01)$.

에는 $60 \mathrm{rpm}$ 으로 하다가 피복 후기에는 최고 $500 \mathrm{rpm}$ 까지 회전속도를 조절하였다고 보고하 였지만 본 연구에서 사용된 피복기계로는 500 $\mathrm{rpm}$ 에서는 피복작업을 수행할 수 없었다. 피복 기계가 서로 다르면 피복시 통의 회전속도에 큰 차이가 있었다. Scott(1997)는 피복통의 속도 별 피복효과 검증에서 석회를 고형물질로 회전 속도를 각각 $29,30,31,32,33,34 \mathrm{rpm}$ 로 시험 한 결과 $31 \mathrm{rpm}$ 에서 가장 좋은 결과를 나타냈

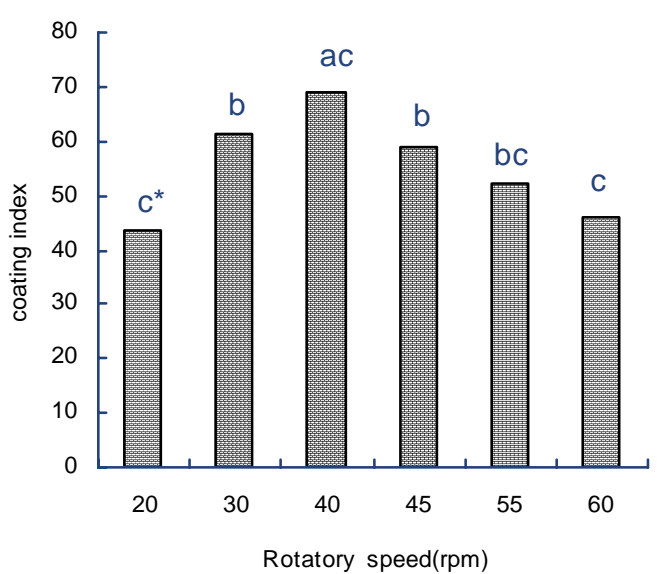

Fig. 2. Effects of coating pan speed on coating index for coating tall fescue seed.

* Bars with different alphabetic letters are significantly different $(\mathrm{p}<0.01)$.

다고 하였다. 본 실험에서는 피복통의 회전속 도에 따라 종자의 피복효과가 크게 달라졌는 데, 피복통의 회전속도가 적정 회전속도보다 높거나 낮으면 피복효과가 크게 낮아졌다. 레 드클로버는 피복통의 회전속도가 $45 \mathrm{rpm}$ 일 때, 톨페스큐는 $40 \mathrm{rpm}$ 에서 단립종자 비율, 덩어리 진 피복종자, 미피복 물질, 피복물질의 탈락성, 백립중 등에서 가장 양호한 피복효과를 보여주 었다. 따라서 피복통의 회전속도는 피복물질의 
물리적 성질에 크게 영향을 미치기 때문에 양 질의 종자피복을 위하여 피복통 회전속도의 표 준화가 필요하였다.

\section{2. 피복통 회전속도별 피복지수}

레드클로버는 $45 \mathrm{rpm}$ 에서 피복지수가 74.64 로 가장 높았으며, $40 \mathrm{rpm}$ 에서는 67.72로 45 $\mathrm{rpm}$ 보다는 약간 낮았으나 통계적인 유의성은 없었다. 그리고 $45 \mathrm{rpm}$ 보다 높거나 낮아짐에 따라 피복지수가 낮아졌다. 톨페스큐에서는 40 $\mathrm{rpm}$ 에서 피복지수가 69.01로 가장 높았으며, $40 \mathrm{rpm}$ 보다 높거나 낮아지면 피복지수는 저하 되었다. 피복지수는 종자피복 후 피복통에서 회수된 전체 무게에 대한 단립 피복종자의 비 율, 덩어리진 피복종자, 피복되지 않고 회수된 미피복물질의 무게비율을 변수로 하여 산출 (Scott 등, 1997; 이 등, 2004) 하였다. 때문에 Table 1과 2의 자료를 바탕으로 Fig. 1과 2의 피복지수가 산출되어 피복종자를 종합적으로 간단하게 판단할 수 있게 되었다. 따라서 피복 종자의 물리적 평가에 피복지수가 좋은 평가지 표가 되었으며, 피복통의 회전속도는 피복종자 의 품질을 평가하는데 중요한 요인이 되었다.

\section{IV. 요 약}

본 실험은 표준화된 피복종자를 생산하기 위 하여 피복통의 회전속도를 $20,30,40,45,55$, $60 \mathrm{rpm}$ 으로 하여 소형 피복통으로 레드클로버 와 톨페스큐 종자를 피복하였다. 고형물질로는 vermiculite를 사용하였고 접착제는 polyvinyl alcohol을 사용하였다. 피복 후 통에서 회수된 단립 피복종자 무게, 서로 달라붙어 덩어리 진 피복종자 무게, 피복되지 않고 회수된 미 피복 물질 무게, 충격에 의한 피복층 탈락성 및 피 복종자의 백립중 등을 조사하여 피복종자의 물 리적 특성을 평가하였으며, 이 자료를 근거로
피복효과를 종합적으로 표현하는 피복지수를 산출하였다. 레드클로버 종자는 통의 회전속도 $45 \mathrm{rpm}$ 에서 회수된 단립 종자 무게가 제일 높 았으며 $(\mathrm{p}<0.01)$, 덩어리진 종자 수가 적고 피복 물질의 탈락율이 적었으며, 피복종자의 백립중 도 가장 무거웠다. 톨페스큐 종자는 피복통 회전속도 $40 \mathrm{rpm}$ 에서 회수된 단립 종자 무게가 제일 높았으며 $(\mathrm{p}<0.01)$, 덩어리진 종자 수가 적 고 피복물질의 탈락율이 적었으며, 피복종자의 백립중도 가장 무거웠다. 통의 회전속도별 피 복지수는 레드클로버는 $45 \mathrm{rpm}$ 에서 $(\mathrm{p}<0.01)$, 톨 페스큐는 $40 \mathrm{rpm}$ 에서 제일 높았다 $(\mathrm{p}<0.01)$. 피 복통의 회전속도는 피복종자의 물리적 성질에 크게 영향을 미치기 때문에 종자피복 전에 종 자나 피복제에 따른 피복통 회전속도의 표준화 가 필수적이라 하겠다.

\section{$\mathrm{V}$. 인 용 문 헌}

1. 강점순, 안종길, 손병구, 최영환. 1999. 파종작업의 생력화와 입묘 증진을 위한 상추 종자의 코팅 기 술 개발. 대산논총(7): 67-84.

2. 이성운, 허삼남, 김택림. 2004. 피복지수에 의한 목초종자 피복제의 물리적 특성 평가. 한초지 24(2):155-162.

3. Fraser, M.E. 1966. Pre-inoculation of lucerne seed. Journal of Applied Bacteriology. 29:587-595.

4. Liu, L.X. and J.D. Litster. 1989. Coating of seeds with fertilizer in a spouted bed. Proceedings of the 17th Australasian Chemical Engineers Conference (Chemeca 89), Gold Coast, August. 23-25:310-317.

5. Liu, L.X. and J.D. Litster. 1990. The effect of process variables on the maximum coating rate in a spouted Auckland New Zealand, August. 27-30: 626-633.

6. SAS. 1991. User's Guide Statistics. Cary. N. C. Statistical Analysis System Institute Inc.

7. Scott, J.M., G.J. Blair and A.C. Andrews. 1997. The mechanics of coating seeds in a small rotating drum. Seed Science and Technology. 25:281-292. (접수일자 : 2008. 1. 31 / 채택일자 : 2008. 3. 7) 